\title{
Antifungal and Antibacterial Metabolites from a French Poplar Type Propolis
}

\author{
Séverine Boisard, ${ }^{1}$ Anne-Marie Le Ray, ${ }^{1}$ Anne Landreau, ${ }^{1}$ Marie Kempf, ${ }^{2,3}$ \\ Viviane Cassisa, ${ }^{2,3}$ Catherine Flurin, ${ }^{4}$ and Pascal Richomme ${ }^{1}$ \\ ${ }^{1}$ EA 921 SONAS/SFR 4207 QUASAV, Université d’Angers, 16 boulevard Daviers, 49045 Angers Cedex 01, France \\ ${ }^{2}$ Laboratoire de Bactériologie-Hygiène, Centre Hospitalier Universitaire, 4 rue Larrey, 49933 Angers Cedex 09, France \\ ${ }^{3}$ Groupe d'Etude des Interactions Hôte Pathogène (GEIHP), Université d'Angers, 4 rue Larrey, 49933 Angers Cedex, France \\ ${ }^{4}$ Ballot-Flurin Apiculteurs-Abeilles Santé, 75 place Lagardère, 65700 Maubourguet, France
}

Correspondence should be addressed to Pascal Richomme; pascal.richomme@univ-angers.fr

Received 2 February 2015; Revised 3 March 2015; Accepted 4 March 2015

Academic Editor: Veronique Seidel

\begin{abstract}
Copyright (C) 2015 Séverine Boisard et al. This is an open access article distributed under the Creative Commons Attribution License, which permits unrestricted use, distribution, and reproduction in any medium, provided the original work is properly cited.

During this study, the in vitro antifungal and antibacterial activities of different extracts (aqueous and organic) obtained from a French propolis batch were evaluated. Antifungal activity was evaluated by broth microdilution on three pathogenic strains: Candida albicans, C. glabrata, and Aspergillus fumigatus. Antibacterial activity was assayed using agar dilution method on 36 Gram-negative and Gram-positive strains including Staphylococcus aureus. Organic extracts showed a significant antifungal activity against C. albicans and C. glabrata $\left(\mathrm{MIC}_{80}\right.$ between 16 and $\left.31 \mu \mathrm{g} / \mathrm{mL}\right)$ but only a weak activity towards A. fumigatus $\left(\mathrm{MIC}_{80}=\right.$ $250 \mu \mathrm{g} / \mathrm{mL}$ ). DCM based extracts exhibited a selective Gram-positive antibacterial activity, especially against S. aureus (SA) and several of its methicillin-resistant (MRSA) and methicillin-susceptible (MSSA) strains $\left(\mathrm{MIC}_{100} 30-97 \mu \mathrm{g} / \mathrm{mL}\right.$ ). A new and active derivative of catechin was also identified whereas a synergistic antimicrobial effect was noticed during this study.
\end{abstract}

\section{Introduction}

Propolis is a resinous natural substance collected by honeybees from buds and exudates of various trees and plants, mixed with beeswax and salivary enzymes. Bees generally use it as a sealer, to smooth out the internal walls of the hive, as well as a protective barrier against intruders. Propolis has been used in folk medicine since ancient times due to its pharmacological potential associated with antioxidant [1-3], antifungal $[4,5]$, antibacterial [6-8], and anti-inflammatory [9] properties.

Propolis is generally composed of $50 \%$ of resin and balm (including polyphenolic compounds), 30\% of wax and fatty acids, $10 \%$ of essential oils, $5 \%$ of pollen, and $5 \%$ of various organic and inorganic compounds. However, the composition of propolis deeply depends on the vegetation at the site of collection [10]. Indeed, propolis from temperate climatic zones, like in Europe, North America, or nontropical regions of Asia, mainly originates from the bud exudates of Populus species (Salicaceae) and consequently is rich in flavonoids and phenolic acids and their esters [11]; however tropical propolis, originating from regions where neither poplars nor birches grow, is rich in prenylated derivatives of $p$-coumaric acids, benzophenones, or terpenoids $[12,13]$.

The antifungal, antibacterial properties and chemical composition of propolis from many countries all over the world have been widely studied $[6,8,14-20]$ but few reports were already given for European propolis [21, 22]. In 1990, Grange and Davey [23] highlighted for the first time the bactericidal activity of a French propolis against Grampositive strains whereas later on, in 2000, Hegazi et al. [22] could associate this antibacterial activity with the presence of benzyl caffeate, pinocembrin, and $p$-coumaric acid.

During a previous study, we have evaluated the antioxidant and anti-AGEs activities of different solvents extracts [water; 95\% EtOH; 70\% EtOH; $\mathrm{MeOH}$; dichloromethane (DCM) and DCM/MeOH/H $\left./ \mathrm{H}_{2} \mathrm{O}(31 / 19 / 4)\right]$ obtained from a French propolis batch and identified their active constituents 
[24]. Here we have investigated the in vitro antifungal and antibacterial activities of these extracts. The antifungal activity was studied on three fungal strains (two yeasts, Candida albicans and C. glabrata, and one filamentous fungus, Aspergillus fumigatus). 36 strains of Gram-positive (including Staphylococcus aureus) and Gram-negative (including Escherichia coli) bacteria were used for the antibacterial assays. During this study, a new secondary metabolite was isolated, namely, 8-[(E)-phenylprop-2-en-1-one]-5-methoxy$( \pm)$-catechin.

\section{Materials and Methods}

2.1. Reagents and Standards. Formic acid, p-coumaric acid, ferulic acid, isoferulic acid, 3,4-dimethoxycinnamic acid, and prenyl caffeate were purchased from Sigma-Aldrich (L'Isle d'Abeau Chesnes, Saint-Quentin-Fallavier, France). Caffeic acid and chrysin were obtained from Acros Organics (Geel, Belgium). Galangin was purchased from Extrasynthese (Genay, France). Pinocembrin and pinobanksin-3-acetate were isolated from the DCM extract of propolis.

2.2. Instrumentation. Optical rotation was measured on a JASCO P-2000 polarimeter. IR spectra were recorded on a Bruker Vertex 70 spectrophotometer. NMR spectra (1D and 2D) were recorded on a Bruker Avance spectrometer at $500 \mathrm{MHz}$ for ${ }^{1} \mathrm{H}$ and $125 \mathrm{MHz}$ for ${ }^{13} \mathrm{C}$. MS analyses were performed on an ESI/APCI Ion Trap Esquire 3000+ from Bruker. UV absorbances were obtained from a Tecan Infinite M200 microplate spectrophotometer.

2.3. Propolis Samples. In order to analyze a typical French batch, that is, exhibiting an average chemical composition, a mixture of samples ( $10 \mathrm{~g}$ of each), collected in apiaries originating from different regions of France, was used for this study. These samples were provided by "Ballot-Flurin Apiculteurs," a company specialized in organic beekeeping. Indeed, even collected in the same geographical region, propolis profiles may differ between apiaries and even inside the same apiary from one hive to another one [25]. Keeping in mind any potential economic development, it then appeared more appropriate to study an industrial end-product, that is, a mixture, exhibiting an average chemical composition associated with an average antimicrobial activity, rather than a specific sample. Therefore, 24 batches of propolis collected over two years (2010 and 2011) from different places in France (cf. supporting information 1; see Supplementary Material available online at http://dx.doi.org/10.1155/2015/319240) were homogeneously mixed to undergo this study.

2.4. Extractions. The extraction processes have been already described [24]. Briefly, the propolis batch was homogeneously pulverized in the presence of liquid nitrogen and divided into $1 \mathrm{~g}$ samples. Four different extractions were then carried out on $1 \mathrm{~g}$ samples with water (E1), 95\% EtOH (E2), $70 \% \mathrm{EtOH}$ (E3), and $\mathrm{MeOH}$ (E4). Then, two extractions, preceded by a cyclohexane wax elimination, were independently performed on $1 \mathrm{~g}$ samples with DCM (E5) and a mixture of DCM, MeOH, and $\mathrm{H}_{2} \mathrm{O}$ (31/19/4) (E6). For E1, a decoction of $1 \mathrm{~g}$ of propolis powder was boiled in $20 \mathrm{~mL}$ $\mathrm{H}_{2} \mathrm{O}$ at $100^{\circ} \mathrm{C}$ for $15 \mathrm{~min}$. After cooling, the solidified wax and the residue were removed by filtration, and the filtrate was evaporated to dryness. For other solvents, $1 \mathrm{~g}$ of propolis powder (or residue obtained from a previous extraction) was macerated in $3 \times 20 \mathrm{~mL}$ of solvent. After stirring for $3 \times 2 \mathrm{~h}$ at room temperature, the mixture was filtered. The filtrates were gathered and evaporated under vacuum. Extraction yields (dried extract/100 g) were as follows: E1 7\%; E2 68\%; E3 65\%; E4 68\%; E5 50\%; and E6 59\%.

2.5. Antifungal Activity. Antifungal activity was assayed on human pathogenic fungi, including two common yeasts (Candida albicans ATCC 66396 and C. glabrata LMA 901085) and an opportunistic mould (Aspergillus fumigatus CBS 11326). The strains were obtained from the Parasitology and Mycology Laboratory at the University Hospital Center of Angers, France. Microorganisms were cultivated at $37^{\circ} \mathrm{C}$ on yeast extract-peptone-dextrose-agar (YPDA) containing $0.5 \mathrm{~g} / \mathrm{L}$ chloramphenicol for two (C. albicans and C. glabrata) or three (A. fumigatus) days. Tests were performed according to a procedure described by Alomar et al. [27], following the guidelines of the approved reference method of the National Committee for Clinical Laboratory Standards (NCCLS) for yeasts [28] and filamentous fungi [29]. Briefly, the yeast suspensions were prepared in RPMI-1640 culture medium and adjusted spectrophotometrically at $630 \mathrm{~nm}$ to reach a final concentration of $\mathrm{ca} .0 .5 \times 10^{3}$ to $2.5 \times 10^{3}$ cells $/ \mathrm{mL}$. The tests were performed using sterile 96 flat shaped well microtiter plates. Serial twofold sample dilutions were made in DMSO. Sample solutions were dispensed at a volume of $5 \mu \mathrm{L}$ in triplicate into the wells to obtain final concentrations from 250 to $1.95 \mu \mathrm{g} / \mathrm{mL}$. After $48 \mathrm{~h}$ at $37^{\circ} \mathrm{C}$ for C. albicans and C. glabrata and $72 \mathrm{~h}$ for A. fumigatus, the spectrophotometric MIC endpoint was calculated from the turbidimetric data as the lowest sample concentration causing a growth inhibition equal to or greater than $80 \%$ of the control $\left(\mathrm{MIC}_{80}\right)$. Amphotericin B was used as a positive control.

2.6. Antibacterial Activity. Antibacterial activity was evaluated on 36 human pathogenic bacterial strains collected by the Laboratory of Bacteriology at the University Hospital Center of Angers, France: seven strains of Acinetobacter baumannii (RCH, SAN008, 12, AYE, CIP7034, 107292, and 5377), two of Escherichia coli (ATCC25922 and a clinical isolate), three of Pseudomonas aeruginosa (ATCC27853 and two clinical isolates), and 4 clinical isolates of Enterobacter cloacae, E. aerogenes, Klebsiella oxytoca, and Salmonella enteritidis (phage type 4) for Gram-negative bacteria; thirteen strains of Staphylococcus aureus (ATCC25923, six methicillinsusceptible clinical isolates, six methicillin-resistant clinical isolates), two clinical isolates of S. epidermidis (methiS and methiR), three clinical isolates of Enterococcus faecalis and one of E. faecium, and one clinical isolate of Corynebacterium striatum for Gram-positive bacteria. Tests were performed using the methodology described by Alomar et al. [30]. Briefly, a stock solution of each sample was prepared in 
triplicate at $20 \mathrm{mg} / \mathrm{mL}$ in DMSO under sterile conditions. Serial dilutions were prepared (sample concentrations: 10, 20, 30 , etc., to $100 \mu \mathrm{g} / \mathrm{mL}$ ) and $0.1 \mathrm{~mL}$ of each dilution was added to $19.9 \mathrm{~mL}$ of Mueller-Hinton agar (Merck, Germany) and transferred to Petri plates. Bacterial strains $\left(2 \times 10^{4} \mathrm{CFU} / \mathrm{mL}\right)$ were suspended in sterile $\mathrm{NaCl}$ aqueous solution $(0.15 \mathrm{M})$ and inoculated on the different Petri plates using the multipoint inoculator (AQS, England). After $24 \mathrm{~h}$ of incubation at $37^{\circ} \mathrm{C}$, the minimum inhibitory concentration $\left(\mathrm{MIC}_{100}\right.$, $\mu \mathrm{g} / \mathrm{mL}$ ) against bacterial strains was defined as the lowest concentration of each sample that inhibited visible growth. A blank was made inoculating the strains on Mueller-Hinton agar without any extract or compound. Oxacillin was used to distinguish the methicillin-resistant from the susceptible staphylococcal strains.

2.7. HPLC-DAD and HPLC-MS Procedures. Dry extracts were dissolved in $\mathrm{MeOH}(5 \mathrm{mg} / \mathrm{mL}$ for the aqueous extract and $10 \mathrm{mg} / \mathrm{mL}$ for the organic solvents ones) and centrifuged at $13000 \mathrm{rpm}$ for $10 \mathrm{~min}$ prior to injection $(10 \mu \mathrm{L})$ into the HPLC system. Analytical HPLC was run on a 2695 Waters separation module equipped with a diode array detector 2996 Waters. Separation was achieved on a LiChrospher column $100 \mathrm{RP}-18(125 \times 4 \mathrm{~mm}$ i.d., $5 \mu \mathrm{m})$ protected with a LiChrocart 4-4 guard cartridge $(4 \times 4 \mathrm{~mm}$ i.d. $)$ at a flow rate of $1 \mathrm{~mL} / \mathrm{min}$. The mobile phase consisted of $0.1 \%$ formic acid in water (solvent A) and $\mathrm{MeOH}$ (solvent $\mathrm{B}$ ) and the separation was performed using the linear gradient: $25-100 \% \mathrm{~B}$ in $40 \mathrm{~min}$. UV detection was achieved at two wavelengths: 254 and $280 \mathrm{~nm}$.

The mass analyses were performed with an ESI interface coupled to an ion trap mass analyzer in both positive and negative modes, with the following conditions: collision gas, He; collision energy amplitude, $1.3 \mathrm{~V}$; nebulizer and drying gas, $\mathrm{N}_{2}, 7 \mathrm{~L} / \mathrm{min}$; pressure of nebulizer gas, 30 psi; dry temperature, $340^{\circ} \mathrm{C}$; flow rate, $1.0 \mathrm{~mL} / \mathrm{min}$; solvent split ratio $1: 9$; scan range, $m / z$ 100-1000.

2.8. Identification of Propolis Constituents. 18 and 22 were directly identified in the DCM extract by HPLC/UV/MS and comparison with the literature data $[31,32]$, whereas 3,6 , $7, \mathbf{8}, 10$, and 32 were compared with authentic standards (Sigma-Aldrich and Acros organics, cf. Section 2.1). A flash chromatography was then carried out in order to identify the other phenolic constituents. $50.0 \mathrm{~g}$ of pulverized propolis was firstly extracted with cyclohexane $(3 \times 200 \mathrm{~mL}, 2 \mathrm{~h}$, room temperature) to eliminate waxes. After filtration, the residue was extracted with DCM $(5 \times 200 \mathrm{~mL}, 2 \mathrm{~h}$, room temperature $)$ to give $25.0 \mathrm{~g}$ of dry DCM extract (50\% yield). $21.0 \mathrm{~g}$ of this extract was fractionated using a CombiFlash Teledyne ISCO apparatus and a prepacked silica gel column (Interchim PF$50 \mathrm{SI} \mathrm{HC/300} \mathrm{g,} 50 \mu \mathrm{m}$ ), at a flow rate of $100 \mathrm{~mL} / \mathrm{min}$ and with the following gradient elution system: cyclohexane $\left(\mathrm{C}_{6} \mathrm{H}_{12}\right)$ $100 \%(2.0 \mathrm{~L}), \mathrm{C}_{6} \mathrm{H}_{12}$ : EtOAc 90:10 (1.7 L), $\mathrm{C}_{6} \mathrm{H}_{12}$ : EtOAc $90: 10$ to $80: 20(2.2 \mathrm{~L}), 80: 20$ to $70: 30(2.5 \mathrm{~L}), \mathrm{C}_{6} \mathrm{H}_{12}:$ EtOAc $70: 30$ to $60: 40(2.2 \mathrm{~L})$, and $\mathrm{C}_{6} \mathrm{H}_{12}:$ EtOAc $60: 40$ to $50: 50$ $(3.0 \mathrm{~L})$ then DCM : MeOH $96: 4$ (2.2 L). UV detection $(\lambda$ 254 and $280 \mathrm{~nm}$ ) and TLC monitoring allowed collecting
21 fractions (F1-21). 48 [33] was identified in F1, 14 [34] and 17 [31] were identified in F11, 1 and 2 [19] were identified in F13, and finally 23 [31] was identified in F15 by HPLC/UV/MS and comparison with the literature data. The remaining constituents were isolated and identified through $1 \mathrm{D}$ and 2D NMR analysis (cf. Section 2.2). $200 \mathrm{mg}$ of F1 was chromatographed on a silica gel column (Grace, $24 \mathrm{~g}$ ) by flash chromatography at a flow rate of $25 \mathrm{~mL} / \mathrm{min}$ with a mixture of $\mathrm{C}_{6} \mathrm{H}_{12}$ and EtOAc (B) [gradient: $1 \% \mathrm{~B}(30 \mathrm{~min}), 2 \% \mathrm{~B}(5 \mathrm{~min})$, $2-5 \% \mathrm{~B}(2 \mathrm{~min}), 5 \% \mathrm{~B}(2 \mathrm{~min}), 5-30 \% \mathrm{~B}(1 \mathrm{~min})$, and $30 \% \mathrm{~B}$ $(5 \mathrm{~min})]$ to give $46[33,35](5 \mathrm{mg}), 47[33,36](3 \mathrm{mg})$, and 49 [37] (5 mg). F2 (1.5 g) gave 43 [38] whereas F4 (696 mg) and F5 (384 mg) allowed us to, respectively, identify 44 [37, 39] and 45 [40]. $500 \mathrm{mg}$ of F6 (1.6 g) was chromatographed on reverse-phase- (RP-) Flash chromatography (Interchim column PF-30C18 HC/6 g, $30 \mu \mathrm{m}$ ) at a flow rate of $15 \mathrm{~mL} / \mathrm{min}$ with water and $\mathrm{MeOH}$ (B) [gradient: $25-30 \% \mathrm{~B}$ (20 min), 30$40 \% \mathrm{~B}(2 \mathrm{~min}), 40 \% \mathrm{~B}(8 \mathrm{~min}), 40-45 \% \mathrm{~B}(1 \mathrm{~min}), 45 \% \mathrm{~B}$ (12 $\mathrm{min}), 45-50 \% \mathrm{~B}(2 \mathrm{~min})$, and $50 \% \mathrm{~B}(20 \mathrm{~min})]$ to give 9 [31] (10 mg), 25 [38] (126 mg), and a mixture of 35 and 36 [34] (15 mg). Similarly $500 \mathrm{mg}$ of F7 was fractionated [gradient: $30-50 \%$ B (25 min), 50-60\% B (25 min), and 60-65\% B (20 min)] to give 11 [41] (2 mg), 33 [31, 42] (128 mg), 34 [38] $(65 \mathrm{mg})$, and 42 [31] (41 mg) whilst $500 \mathrm{mg}$ of F8 [gradient: $30-45 \%$ B (20 min), $45 \%$ B (30 min), $45-48 \%$ B (5 min), $48-$ $55 \% \mathrm{~B}(5 \mathrm{~min}), 55 \% \mathrm{~B}(8 \mathrm{~min}), 55-60 \% \mathrm{~B}(1 \mathrm{~min})$, and $60 \%$ B (12 min)] gave 13 [38] (3 mg), 28 [31, 43] (224 mg), and 41 [34] (28 mg). $500 \mathrm{mg}$ of F9 [gradient: $30-60 \% \mathrm{~B}$ (50 min) and $60-65 \% \mathrm{~B}(5 \mathrm{~min})]$ yielded mixture of 4 [34] and $5[44,45]$ (8 mg), 15 [43] (33 mg), 24 [32, 46] (16 mg), 32 [38] (150 mg), and another mixture of 37 [16] and 38 [32] (3 mg). 27 [34] and 29 [31] were identified from F10 (1.3 g). $500 \mathrm{mg}$ of F11 [flow rate of $20 \mathrm{~mL} / \mathrm{min}$, gradient: $25-75 \% \mathrm{~B}$ (55 min)] gave 26 [47] (82 mg), 31 [31] (56 mg), and 39 [32] (70 mg). $300 \mathrm{mg}$ of F13 [flow rate of $15 \mathrm{~mL} / \mathrm{min}$, gradient: $30-45 \% \mathrm{~B}$ (20 $\mathrm{min}), 45 \% \mathrm{~B}$ (20 min), $45-50 \% \mathrm{~B}$ (10 $\mathrm{min}), 50-60 \% \mathrm{~B}(5 \mathrm{~min})$, and $60 \% \mathrm{~B}$ (5 min)] gave 10 [31] (2 mg) and $\mathbf{1 6}$ [38] (3 mg). 30 [48] was directly identified in F17 (543 mg). $500 \mathrm{mg}$ of F18 [gradient: $40 \% \mathrm{~B}$ (7 min), $40-50 \% \mathrm{~B}$ ( $2 \mathrm{~min}$ ), and $50 \% \mathrm{~B}$ (30 min)] gave a mixture of $\mathbf{8}$ and $\mathbf{1 2}$ (cf. F19) together with the new compound 40 (12 mg). $500 \mathrm{mg}$ of F19 was chromatographed [gradient: $25 \% \mathrm{~B}$ (25 $\mathrm{min}), 25-35 \% \mathrm{~B}(1 \mathrm{~min})$, and $35 \% \mathrm{~B}(20 \mathrm{~min})]$ to give $\mathbf{8}$ (8 mg) and 12 (26 mg) [31]. Finally $500 \mathrm{mg}$ of F20 allowed us to isolate [gradient: $30-40 \% \mathrm{~B}$ (20 min), 40-43\% B (20 min), and 43-50\% B (10 min)] 19 [32] (3 mg) and a mixture of 20 [49] and 21 [50] (7 mg).

\section{Results and Discussion}

3.1. Antifungal and Antibacterial Activities. Table 1 shows the minimum inhibitory concentration of at least $80 \%$ of fungal growth $\left(\mathrm{MIC}_{80}\right)$ obtained with E1-6 extracts for Candida albicans, C. glabrata, and Aspergillus fumigatus. E1 did not exhibit any interesting antifungal activity $\left(\mathrm{MIC}_{80}>250 \mu \mathrm{g} / \mathrm{mL}\right.$ for the three strains) whereas E2-6 showed significant antifungal activities $\left(\mathrm{MIC}_{80}\right.$ between 16 and $\left.31 \mu \mathrm{g} / \mathrm{mL}\right)$ on both $C$. albicans and C. glabrata. These results are in agreement with those previously obtained for an Argentinian propolis 
TABle 1: Antifungal activity against Candida albicans, C. glabrata, and Aspergillus fumigatus.

\begin{tabular}{lcccc}
\hline Extract & Solvent & C. albicans & $\begin{array}{c}\text { C. glabrata } \\
\mathrm{MIC}_{80}(\mu \mathrm{g} / \mathrm{mL})\end{array}$ \\
\hline E1 & $\mathrm{H}_{2} \mathrm{O}$ & $>250$ & $>250$ & $>250$ \\
E2 & $95 \% \mathrm{EtOH}$ & 31.25 & 15.63 & 250 \\
$\mathrm{E} 3$ & $70 \% \mathrm{EtOH}$ & 31.25 & 31.25 & 250 \\
$\mathrm{E} 4$ & $\mathrm{MeOH}$ & 31.25 & 31.25 & 250 \\
E5 & $\mathrm{DCM}$ & 31.25 & 31.25 & 250 \\
E6 & Mixed solvents & 15.63 & 31.25 & 250 \\
\multicolumn{2}{c}{ Amphotericin B } & 0.125 & 0.125 & 6 \\
\hline
\end{tabular}

on several Candida species $\left(\mathrm{MIC}_{100}\right.$ in a range of 31 to $125 \mu \mathrm{g} / \mathrm{mL}$ ) [51] as well as with Greece and Cyprus ones $\left(\mathrm{MIC}_{100} 20 \mu \mathrm{g} / \mathrm{mL}\right)$ [21]. E2-6 also exhibited a weak activity towards $A$. fumigatus $\left(\mathrm{MIC}_{80} 250 \mu \mathrm{g} / \mathrm{mL}\right)$.

According to Ríos and Recio [52] a $\mathrm{MIC}_{100}<100 \mu \mathrm{g} / \mathrm{mL}$ should be considered as a promising value for a crude extract (versus $10 \mu \mathrm{g} / \mathrm{mL}$ for pure compounds). This is the reason why Table 2 gives the results of the antibacterial activity of E1-6 at the concentration of $100 \mu \mathrm{g} / \mathrm{mL}$ for 28 strains of Gramnegative and Gram-positive bacteria.

Results showed that Gram-negative bacteria were not susceptible to E1-6 at this concentration. In contrast, organic solvents extracts were active on several Gram-positive bacteria such as Corynebacterium striatum (sometimes involved in pleuropulmonary infections) (E2-5) and especially Staphylococcus aureus, including for the latter several methicillinresistant (MRSA) and methicillin-susceptible (MSSA) clinical isolates (E5-6). Sometimes called "golden staph," S. aureus is the most pathogenic species of Staphylococcus genus. It might cause food poisoning, skin infections, abscesses, and diseases like pneumonia, meningitis, and sepsis. S. aureus is additionally one of the major causes of hospital-acquired infections, and the treatment of some multiresistant strains has become quite problematic. Among them, MRSA appears in France as one of the most commonly multiresistant strains encountered in hospitals.

$\mathrm{MIC}_{100}$ of E1-6 were determined on the 6 susceptible Gram-positive strains as well as on 8 other MRSA and MSSA strains. Results are given in Table 3.

E1 did not show any interesting activity on the 14 studied strains $\left(\mathrm{MIC}_{100}>100 \mu \mathrm{g} / \mathrm{mL}\right)$. E2-6 showed interesting activities against Corynebacterium striatum with $\mathrm{MIC}_{100}$ ranging from 63 to $90 \mu \mathrm{g} / \mathrm{mL}$. E5 and E6 exhibited the best antibacterial activities against the Staphylococcus strains with $\mathrm{MIC}_{100}$ up to 57 and $30 \mu \mathrm{g} / \mathrm{mL}$, respectively. Among the alcoholic extracts, only $\mathrm{E} 4$ showed a moderate activity $\left(\mathrm{MIC}_{100} 90 \mu \mathrm{g} / \mathrm{mL}\right)$ against $S$. aureus and one MRSA whereas E2 and E3 appeared as inactive. These overall activities therefore appeared to be better than those reported by Grange and Davey for the antibacterial activity of a French propolis on S. aureus and MRSA $\left(\mathrm{MIC}_{100} 188-375 \mu \mathrm{g} / \mathrm{mL}\right)$ [23]. Our global antibacterial activity against MRSA and MSSA could be compared with those reported for propolis collected in Solomon Islands, exhibiting $\mathrm{MIC}_{100}$ between

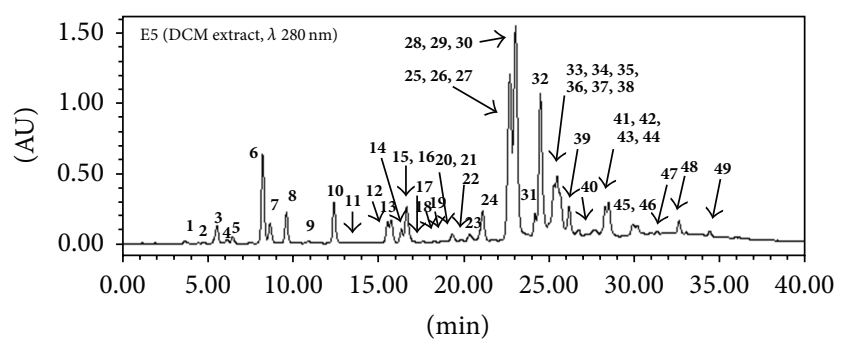

Figure 1: HPLC chromatograms of E5: 1 3,4-dihydroxybenzaldehyde, 2 4-hydroxybenzoic acid, 3 caffeic acid, 4 vanillin, 5 4hydroxyacetophenone, 6 p-coumaric acid, 7 ferulic acid, 8 isoferulic acid, 9 benzoic acid, 10 3,4-dimethoxycinnamic acid, 11 3phenylpropanoic acid, 12 pinobanksin-5-methyl ether, 13 cinnamic acid, 14 4-methoxycinnamic acid, 15 pinobanksin, 16 naringenin, 17 quercetin, 18 quercetin-3-methyl ether, 19 pinocembrin-5methyl ether, 20 1,3-di-p-coumaroylglycerol, 21 1-p-coumaroyl-3feruloylglycerol, 22 kaempferol, 23 apigenin, 24 cinnamylidene acetic acid, 25 pinocembrin, 26 benzyl caffeate, 27 isopent-3-enyl caffeate, 28 pinobanksin-3-acetate, 29 prenyl caffeate, 302 -acetyl1,3-dicoumaroylglycerol, 31 phenylethyl caffeate (CAPE), 32 chrysin, 33 benzyl $p$-coumarate, 34 galangin, 35 benzyl ferulate, 36 prenyl ferulate, 37 kaempferide, 38 rhamnocitrin, 39 cinnamyl caffeate, 40 8-[(E)-phenylprop-2-en-1-one]-5-methoxy- $( \pm)$-catechin (new), 41 cinnamyl isoferulate, $\mathbf{4 2}$ cinnamyl $p$-coumarate, $\mathbf{4 3}$ pinostrobin, 44 alpinone-3-acetate, 45 tectochrysin, 46 benzyl cinnamate, 47 cinnamyl benzoate, 48 cinnamyl cinnamate, and 49 cinnamyl cinnamylidene acetate.

64 and $128 \mu \mathrm{g} / \mathrm{mL}$ [6]. Similarly E4 was more active than a methanolic propolis extract from Jordan $(585 \mu \mathrm{g} / \mathrm{mL}$ against S. aureus and $4700 \mu \mathrm{g} / \mathrm{mL}$ against MRSA) [20].

These results suggested that antifungal and antibacterial activities of propolis extracts could be related to their flavonoids contents [24]. Indeed, whereas E1-6 exhibited high total polyphenol contents (239-281 mg GAE/g), only those showing both high flavone/flavonol (FF) and flavanone/dihydroflavonol (FD) contents (i.e., E5-6) were active on the studied strains. In addition the higher the cumulative contents FF+FD were, the stronger the antibacterial activity was, as shown with E5 $(254 \mathrm{mg} / \mathrm{g})$ and E6 $(236 \mathrm{mg} / \mathrm{g})>$ E2-4 (220-228 mg/g). These results are in agreement with those reported by Velazquez et al. [15] for different Mexican propolis collected in Sonora State where EEP from the areas of Ures ( $410 \mathrm{mg} / \mathrm{g}$ ), Caborca (332 mg/g), and Pueblo de Alamos $(209 \mathrm{mg} / \mathrm{g})$ showed $\mathrm{MIC}_{100}$ against S. aureus of 100 , 200 , and $>400 \mu \mathrm{g} / \mathrm{mL}$, respectively.

3.2. Chemical Composition. Figure 1 shows the HPLC chromatogram of the DCM extract E5. 48 compounds were identified by comparison with the literature data (UV/MS) and pure standards or, when needed, through ${ }^{1} \mathrm{H}$ and ${ }^{13} \mathrm{C}(1 \mathrm{D}$ and 2D) NMR analysis after compound isolation.

Additionally a new flavan-3-ol was identified as the 8-[(E)-phenylprop-2-en-1-one]-5-methoxy- $( \pm)$-catechin 40 (Figure 2).

Compound $\mathbf{4 0}$ was obtained as a yellow amorphous solid $(0.6 \mu \mathrm{g} / \mathrm{g}$ of DCM extract). The molecular formula was 
TABLE 2: Antibacterial activity of E1-6 against 28 Gram-negative and Gram-positive strains.

\begin{tabular}{|c|c|c|c|c|c|c|c|}
\hline \multirow{2}{*}{ Number } & \multirow{2}{*}{ Bacterial strains } & \multicolumn{6}{|c|}{ Extracts $(100 \mu \mathrm{g} / \mathrm{mL})$} \\
\hline & & $\mathrm{E} 1: \mathrm{H}_{2} \mathrm{O}$ & E2: 95\% EtOH & E3: $70 \% \mathrm{EtOH}$ & $\mathrm{E} 4: \mathrm{MeOH}$ & E5: DCM & E6: mixed solvents \\
\hline \multicolumn{8}{|c|}{ Gram-negative: } \\
\hline 1 & Acinetobacter baumannii (RCH) & - & - & - & - & - & - \\
\hline 2 & Acinetobacter baumannii (SAN008) & - & - & - & - & - & - \\
\hline 3 & Acinetobacter baumannii (12) & - & - & - & - & - & - \\
\hline 4 & Acinetobacter baumannii (AYE) & - & - & - & - & - & - \\
\hline 5 & Acinetobacter baumannii (CIP7034) & - & - & - & - & - & - \\
\hline 6 & Acinetobacter baumannii (CIP107292) & - & - & - & - & - & - \\
\hline 7 & Acinetobacter baumannii (CIP5377) & - & - & - & - & - & - \\
\hline 8 & Enterobacter cloacae (0705A1743) & - & - & - & - & - & - \\
\hline 9 & Enterobacter aerogenes (0705A0867) & - & - & - & - & - & - \\
\hline 10 & Escherichia coli (ATCC25922) & - & - & - & - & - & - \\
\hline 11 & Escherichia coli (0705A0434) & - & - & - & - & - & - \\
\hline 12 & Klebsiella oxytoca (0705C0187) & - & - & - & - & - & - \\
\hline 13 & Pseudomonas aeruginosa (ATCC27853) & - & - & - & - & - & - \\
\hline 14 & Pseudomonas aeruginosa (0704C0134) & - & - & - & - & - & - \\
\hline 15 & Pseudomonas aeruginosa $(0703 \mathrm{C} 0259)$ & - & - & - & - & - & - \\
\hline 16 & Salmonella enteritidis (4) & - & - & - & - & - & - \\
\hline \multicolumn{8}{|c|}{ Gram-positive: } \\
\hline 17 & Corynebacterium striatum (56) & - & + & + & + & + & + \\
\hline 18 & Enterococcus faecalis (11003508001) & - & - & - & - & - & - \\
\hline 19 & Enterococcus faecalis (11003492701) & - & - & - & - & - & - \\
\hline 20 & Enterococcus faecalis (11004774001) & - & - & - & - & - & - \\
\hline 21 & Enterococcus faecium (11502441401) & - & - & - & - & - & - \\
\hline 22 & Staphylococcus aureus (ATCC25923) & - & - & - & + & + & + \\
\hline 23 & $M R S A(0706 \mathrm{C} 0025)$ & - & - & - & + & + & + \\
\hline 24 & MRSA (0702E0196) & - & - & - & - & + & + \\
\hline 25 & MSSA (0703H0036) & - & - & - & - & - & - \\
\hline 26 & MSSA (0701A0095) & - & - & - & - & + & + \\
\hline 27 & S. epidermidis methiS ${ }^{\mathrm{a}}(12004523201)$ & - & - & - & - & - & - \\
\hline 28 & S. epidermidis methi $R^{\mathrm{b}}$ (12552599902) & - & - & - & - & - & - \\
\hline
\end{tabular}

-: no antibacterial activity, + : antibacterial activity, ${ }^{\mathrm{a}}$ methicillin-Susceptible, ${ }^{\mathrm{b}}$ methicillin-Resistant.

TABLE 3: MICs of E1-6 against 14 Gram-positive strains including MRSA and MSSA.

\begin{tabular}{|c|c|c|c|c|c|c|c|c|}
\hline \multirow{2}{*}{ Number } & \multirow{2}{*}{ Bacterial strains } & \multicolumn{6}{|c|}{$\mathrm{MIC}_{100}(\mu \mathrm{g} / \mathrm{mL})$} & \multirow[b]{2}{*}{ Oxacillin } \\
\hline & & $\mathrm{E} 1: \mathrm{H}_{2} \mathrm{O}$ & E2: $95 \% \mathrm{EtOH}$ & E3: $70 \% \mathrm{EtOH}$ & $\mathrm{E} 4: \mathrm{MeOH}$ & E5: DCM & E6: mixed solvents & \\
\hline 17 & Corynebacterium striatum & $>100$ & $83 \pm 6$ & $90 \pm 0$ & $77 \pm 12$ & $63 \pm 15$ & $87 \pm 21$ & - \\
\hline 22 & Staphylococcus aureus (ATCC25923) & $>100$ & $>100$ & $>100$ & $90 \pm 0$ & $60 \pm 10$ & $67 \pm 15$ & $\leq 0.25$ \\
\hline 23 & $M R S A(0706 \mathrm{C} 0025)$ & $>100$ & $>100$ & $>100$ & $90 \pm 0$ & $57 \pm 12$ & $30 \pm 0$ & $\geq 4$ \\
\hline 24 & MRSA (0702E0196) & $>100$ & $>100$ & $>100$ & $>100$ & $80 \pm 10$ & $77 \pm 23$ & $\geq 4$ \\
\hline 25 & MSSA (0703H0036) & $>100$ & $>100$ & $>100$ & $>100$ & $>100$ & $>100$ & $\leq 0.25$ \\
\hline 26 & MSSA (0701A0095) & $>100$ & $>100$ & $>100$ & $>100$ & $87 \pm 6$ & $83 \pm 29$ & $\leq 0.25$ \\
\hline 29 & MRSA (11004533801) & $>100$ & $>100$ & $>100$ & $>100$ & $80 \pm 0$ & $87 \pm 21$ & $\geq 4$ \\
\hline 30 & MRSA (11004691801) & $>100$ & $>100$ & $>100$ & $>100$ & $77 \pm 6$ & $67 \pm 23$ & $\geq 4$ \\
\hline 31 & MRSA (11004787401) & $>100$ & $>100$ & $>100$ & $>100$ & $97 \pm 6$ & $>100$ & $\geq 4$ \\
\hline 32 & MRSA (11006153901) & $>100$ & $>100$ & $>100$ & $>100$ & $77 \pm 6$ & $73 \pm 29$ & $\geq 4$ \\
\hline 33 & MSSA (11004327701) & $>100$ & $>100$ & $>100$ & $>100$ & $77 \pm 6$ & $73 \pm 12$ & 0.25 \\
\hline 34 & MSSA (11004480701) & $>100$ & $>100$ & $>100$ & $>100$ & $80 \pm 0$ & $97 \pm 12$ & 0.5 \\
\hline 35 & MSSA (11004691801) & $>100$ & $>100$ & $>100$ & $>100$ & $77 \pm 6$ & $90 \pm 17$ & 0.5 \\
\hline 36 & MSSA (11004010401) & $>100$ & $>100$ & $>100$ & $>100$ & $77 \pm 6$ & $90 \pm 0$ & $\leq 0.25$ \\
\hline
\end{tabular}


<smiles>COc1cc(O)c(C(=O)/C=C/c2ccccc2)c2c1CC(O)C(c1ccc(O)c(O)c1)O2</smiles>

40

FIgURE 2: Chemical structure of the new compound $\mathbf{4 0 .}$

determined as $\mathrm{C}_{25} \mathrm{H}_{22} \mathrm{O}_{7}$ by HRESIMS (found for $[\mathrm{M}+\mathrm{H}]^{+}$ 435.1436; calculated 435.1438). The UV spectrum showed an absorption maximum at $350 \mathrm{~nm}$. The IR spectrum indicated the presence of $\mathrm{OH}\left(3400 \mathrm{~cm}^{-1}\right)$ as well as conjugated ketone carbonyl $\left(1610 \mathrm{~cm}^{-1}\right)$ groups. The ${ }^{1} \mathrm{H}$ NMR spectrum exhibited signals due to a hydrogen-bonded $\mathrm{OH}$ at $\delta_{\mathrm{H}} 14.49$, two trans-olefinic protons $\left(\delta_{\mathrm{H}} 8.06\right.$ and 7.63, $\left.2 \mathrm{~d}, J=15.7 \mathrm{~Hz}\right)$, aromatic rings $\left(9 \mathrm{H}, \delta_{\mathrm{H}} 6.15-7.30\right)$, and one methoxyle $\left(\delta_{\mathrm{H}}\right.$ $3.92)$. It also showed the characteristic signals of a flavan-3ol moiety at $\delta_{\mathrm{H}} 4.68\left(1 \mathrm{H}, \mathrm{d}, J=8.9 \mathrm{~Hz}, \mathrm{H}_{2}\right), 4.21\left(1 \mathrm{H}, \mathrm{m}, \mathrm{H}_{3}\right)$, $3.07\left(1 \mathrm{H}, \mathrm{dd}, J=16.2,5.7 \mathrm{~Hz}, \mathrm{H}_{4 \mathrm{a}}\right)$, and $2.53(1 \mathrm{H}, \mathrm{dd}, J=16.2$, $\left.9.5 \mathrm{~Hz}, \mathrm{H}_{4 \mathrm{~b}}\right)$. The ${ }^{13} \mathrm{C} \mathrm{NMR}$ and HMQC spectra confirmed the presence of 25 carbons with typical flavan-3-ol signals at $\delta_{\mathrm{C}} 84.2\left(\mathrm{C}_{2}\right), 66.8\left(\mathrm{C}_{3}\right)$, and $30.6\left(\mathrm{C}_{4}\right)$. In the ${ }^{1} \mathrm{H}$ NMR spectrum, the signals at $\delta_{\mathrm{H}} 7.11(1 \mathrm{H}, \mathrm{d}, J=1.4 \mathrm{~Hz}), 6.96(1 \mathrm{H}$, $\mathrm{dd}, J=8.4,1.4 \mathrm{~Hz})$, and $6.91(1 \mathrm{H}, \mathrm{d}, J=8.4 \mathrm{~Hz})$ suggested the presence of a $1^{\prime}, 3^{\prime}, 4^{\prime}$-trisubstituted ring $\mathrm{B}$ whereas a singlet at $\delta_{\mathrm{H}} 6.15(1 \mathrm{H})$ indicated a pentasubstituted ring A. Two multiplets at $\delta_{\mathrm{H}} 7.17(2 \mathrm{H})$ and $7.29(3 \mathrm{H})$ revealed the presence of a phenyl residue. The HMBC spectrum showed a longrange correlation between the two trans-olefinic protons $\left[\delta_{\mathrm{H}}\right.$ $7.63\left(1 \mathrm{H}, \mathrm{d}, J=15.7, \mathrm{H}_{\alpha}\right)$ and $8.06(1 \mathrm{H}, \mathrm{d}, J=15.7$, $\left.\mathrm{H}_{\beta}\right)$ ] and the ketone carbon at $\delta_{\mathrm{C}}$ 193.2. This correlation revealed the presence of an $\alpha, \beta$-unsaturated ketone group. The trans-olefinic proton $\mathrm{H}_{\beta}$ at $\delta_{\mathrm{H}} 8.06$ was also correlated with the phenyl quaternary carbon at $\delta_{\mathrm{C}} 136.2\left(\mathrm{C}_{1^{\prime \prime}}\right)$. This correlation implied the presence of a $(2 E)$-4-phenylprop2-en-1-one moiety. A correlation between the methoxyle protons $\left(\delta_{\mathrm{H}} 3.92\right)$ and the carbon at $\delta_{\mathrm{C}} 165.1\left(\mathrm{C}_{5}\right)$ proved that the $\mathrm{OCH}_{3}$ was attached to $\mathrm{C}_{5}$. The NOESY spectrum showed that this methoxyle was spatially close to the proton at $\delta_{\mathrm{H}} 6.15\left(\mathrm{H}_{6}\right)$, whereas a long-range COSY indicated a correlation between $\mathrm{H}_{6}$ and one of the hydroxyl groups at $\delta_{\mathrm{H}} 14.49\left(\mathrm{OH}_{7}\right)$. Therefore a $(2 \mathrm{E})$-4-phenylprop-2-en-1-one moiety was located at $\mathrm{C}_{8}\left(\delta_{\mathrm{C}} 105.9\right)$. Finally, it appeared that the aromatic ring $\mathrm{B}$ was substituted at $\mathrm{C}_{3^{\prime}}$ and $\mathrm{C}_{4^{\prime}}$ by two hydroxyl groups (NMR spectra cf. supporting information 2). ${ }^{1} \mathrm{H}$ and ${ }^{13} \mathrm{C}$ NMR data together with 2D NMR correlations for 40 are summarized in Table 4 and Figure 3.

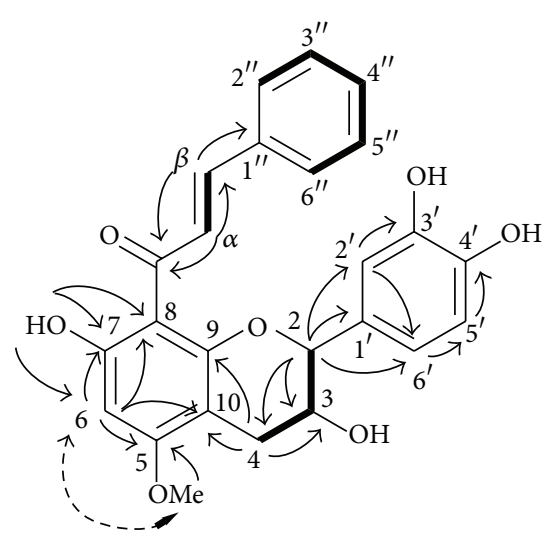

40

FIgure 3: 2D NMR studies of compound 40: COSY (bold lines), selected HMBC (solid arrows: ${ }^{1} \mathrm{H} \rightarrow{ }^{13} \mathrm{C}$ ), and NOESY (dashed arrows) correlations.

TABle 4: ${ }^{1} \mathrm{H}$ and ${ }^{13} \mathrm{C}$ NMR data of the new compound 40 (in acetone-d6).

\begin{tabular}{|c|c|c|}
\hline \multirow{2}{*}{ Position } & \multicolumn{2}{|c|}{40} \\
\hline & $\delta_{\mathrm{H}}$, mult. $(J$ in $\mathrm{Hz})$ & $\delta_{\mathrm{C}}$, mult. \\
\hline 2 & $4.68, \mathrm{~d}(8.9)$ & $84.2, \mathrm{CH}$ \\
\hline 3 & $4.21, \mathrm{~m}$ & $66.8, \mathrm{CH}$ \\
\hline \multirow[t]{2}{*}{4} & a 3.07 , dd $(16.2,5.7)$ & $30.6, \mathrm{CH}_{2}$ \\
\hline & b 2.53 , dd $(16.2,9.5)$ & \\
\hline 5 & & 165.1, qC \\
\hline 6 & $6.15, \mathrm{~s}$ & 93.5, CH \\
\hline 7 & & $168.1, \mathrm{qC}$ \\
\hline 8 & & 105.9, qC \\
\hline 9 & & 157.6, qC \\
\hline 10 & & $102.4, \mathrm{qC}$ \\
\hline $1^{\prime}$ & & 130.7, qC \\
\hline $2^{\prime}$ & 7.11, d (1.4) & $116.2, \mathrm{CH}$ \\
\hline $3^{\prime}$ & & 146.6, qC \\
\hline $4^{\prime}$ & & $146.2, \mathrm{qC}$ \\
\hline $5^{\prime}$ & 6.91, d (8.4) & $116.0, \mathrm{CH}$ \\
\hline $6^{\prime}$ & $6.96, \mathrm{dd}(8.4,1.4)$ & $121.3, \mathrm{CH}$ \\
\hline $1^{\prime \prime}$ & & 136.2, qC \\
\hline $2^{\prime \prime}$ & $7.28, \mathrm{~m}$ & $129.2, \mathrm{CH}$ \\
\hline $3^{\prime \prime}$ & $7.16, \mathrm{~m}$ & 129.7, CH \\
\hline $4^{\prime \prime}$ & $7.28, \mathrm{~m}$ & $130.8, \mathrm{CH}$ \\
\hline $5^{\prime \prime}$ & $7.16, \mathrm{~m}$ & 129.7, CH \\
\hline $6^{\prime \prime}$ & $7.28, \mathrm{~m}$ & $129.2, \mathrm{CH}$ \\
\hline $\mathrm{OH}-7$ & $14.49, \mathrm{~s}$ & \\
\hline$\alpha$ & 7.63, d (15.7) & $143.1, \mathrm{CH}$ \\
\hline$\beta$ & $8,06, d(15.7)$ & $128.4, \mathrm{CH}$ \\
\hline $\mathrm{C}=\mathrm{O}$ & & 193.2, qC \\
\hline $\mathrm{OCH}_{3}-5$ & $3.92, \mathrm{~s}$ & $56.5, \mathrm{CH}_{3}$ \\
\hline
\end{tabular}

40 had no optical rotation and, thus, was isolated here as a racemate mixture of 8 -[(E)-phenylprop-2-en-1-one](2R,3S)-5-methoxycatechin (40a) and 8-[(E)-phenylprop2-en-1-one]-(2S,3R)-5-methoxycatechin (40b). Sha et al. 


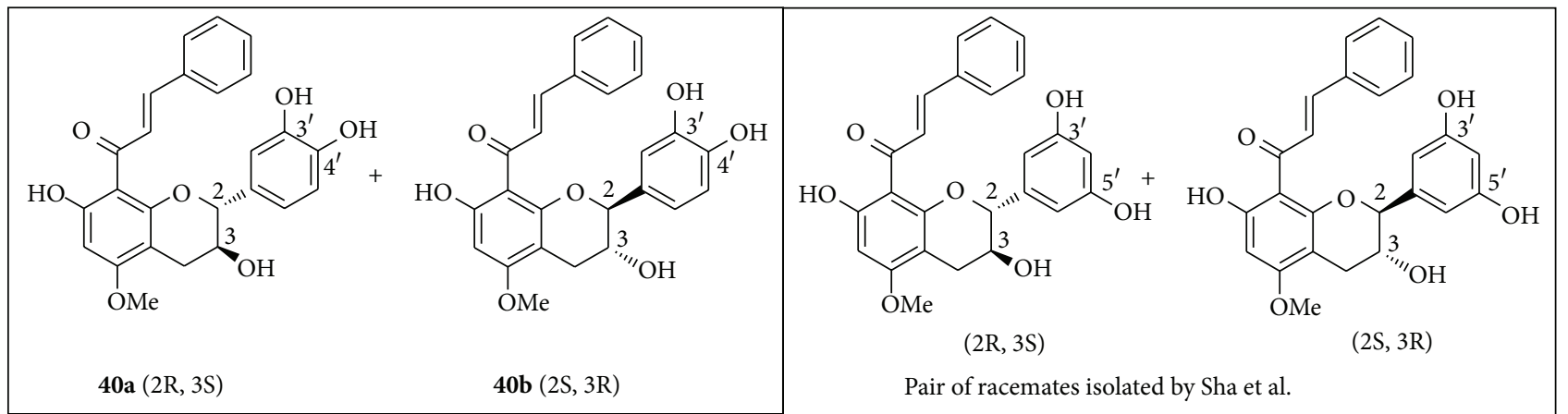

FIGURE 4: Structures of 8-[(E)-phenylprop-2-en-1-one]-(2R,3S)-5-methoxycatechin (40a) and 8-[(E)-phenylprop-2-en-1-one]-(2S,3R)-5methoxycatechin (40b) and a similar pair of racemates isolated by Sha et al. 2009 [26].

TABLE 5: Antifungal and antibacterial activities of $\mathbf{4 0 .}$

\begin{tabular}{lcccc}
\hline \multicolumn{2}{c}{ Antifungal activity } & \multicolumn{3}{c}{ Antibacterial activity } \\
Fungal strains & MIC $_{80}(\mu \mathrm{g} / \mathrm{mL})$ & Number & Bacterial strains & $\mathrm{MIC}_{100}(\mu \mathrm{g} / \mathrm{mL})$ \\
\hline C. albicans & $>250$ & 22 & S. aureus (ATCC25923) & $>100$ \\
C. glabrata & $>250$ & 23 & MRSA (0706C0025) & $\leq 10$ \\
A. fumigatus & $>250$ & 24 & MRSA $(0702 \mathrm{E} 0196)$ & $\leq 10$ \\
& & 25 & MSSA $(0703 \mathrm{H} 0036)$ & $>100$ \\
& & 26 & MSSA $(0701 \mathrm{~A} 0095)$ & $>100$ \\
\hline
\end{tabular}

already isolated a similar compound, only differing from $\mathbf{4 0}$ by a $1^{\prime}, 3^{\prime}, 5^{\prime}$-trisubstituted aromatic ring $\mathrm{B}$, from a Chinese propolis [26] (Figure 4).

3.3. Antifungal and Antibacterial Activities of 40. The new flavan-3-ol 40 did not show any antifungal activity on the three strains studied (Table 5). However, though active neither on $S$. aureus nor on MSSA, its $\mathrm{MIC}_{100}$ on MRSA numbers 23 and 24 were lower or equal to $10 \mu \mathrm{g} / \mathrm{mL}$ (close to oxacillin: $\geq 4 \mu \mathrm{g} / \mathrm{mL}$ ).

3.4. Major Compounds Activities. Antifungal and antibacterial activities were then individually evaluated for the five major compounds identified in E2-6, namely, pinobanksin3-acetate (28), pinocembrin (25), chrysin (32), galangin (34), and prenyl caffeate (29) [24]. Their $\mathrm{MIC}_{80}$ towards $C$. albicans, C. glabrata, and A. fumigatus as well as their $\mathrm{MIC}_{100}$ towards $S$. aureus, MRSA, and MSSA are given in Table 6.

Pinobanksin-3-acetate (28), chrysin (32), and galangin (34) appeared as inactive. Pinocembrin (25) showed a moderate activity towards Candida albicans, C. glabrata $\left(\mathrm{MIC}_{80}\right.$ $62-125 \mu \mathrm{g} / \mathrm{mL})$, and $S$. aureus $\left(\mathrm{MIC}_{100} 100 \mu \mathrm{g} / \mathrm{mL}\right)$. Overall prenyl caffeate (29) exhibited the best activities $\left(\mathrm{MIC}_{100}\right.$ up to $16 \mu \mathrm{g} / \mathrm{mL}$ against C. glabrata and up to $63 \mu \mathrm{g} / \mathrm{mL}$ against $S$. aureus and MRSA). Even so it appeared that these compounds were not individually as active as it could be expected from E5-6 results $\left(\mathrm{MIC}_{100} 30-97 \mu \mathrm{g} / \mathrm{mL}\right)$. As far as S. aureus and MRSA are concerned, this kind of synergistic effects was recently pointed out by Darwish et al. [20] who evaluated the antibacterial activities of pinobanksin-3-acetate, pinocembrin, and chrysin isolated from a Jordanian propolis. Therefore these results are also in agreement with Kujumgiev et al. stating that, in spite of a great chemodiversity, no specific compounds can be associated with the antimicrobial activities of propolis extracts whereas, obviously, different flavonoid combinations are essential for these activities [7]. The antimicrobial of propolis extracts most probably involves a complex mechanism. It can be attributed to the synergistic effects of phenolic compounds such as cinnamic acid and ester derivatives, including caffeic acid and CAPE, as well as flavonoids including quercetin and naringenin $[17,53,54]$. Indeed, each of these compounds would be able to increase membrane permeability and inhibit bacterial mobility [54], thus contributing to the antimicrobial activity of propolis but also to its synergism with other antibiotics $[53,55,56]$. It is the reason why Stepanović et al. could notice the antibacterial and synergistic actions of propolis extracts with ampicillin, ceftriaxone, and doxycycline towards Staphylococcus aureus and with nystatin towards Candida albicans, stating that the bacterial resistance to antibiotics had no influence on the susceptibility to propolis extracts [57]. In vitro studies of synergism carried by Fernandes Jr. et al. also revealed synergistic effects of EEP with chloramphenicol, gentamicin, netilmicin, tetracycline, vancomycin, and clindamycin [58]. Therefore our findings are in total accordance with these results and, now that antibiotic resistance to bacteria has become a major public health concern [59], could bring valuable knowledge to develop new antimicrobial drugs for challenging $S$. aureus infections.

\section{Conclusions}

On the basis of these results, it may be concluded that organic solvents extracts of a French poplar type propolis are 
TABLE 6: Antifungal and antibacterial activities of five major compounds.

\begin{tabular}{|c|c|c|c|c|c|c|c|}
\hline & \multirow[b]{2}{*}{ Antifungal strains } & \multicolumn{6}{|c|}{$\mathrm{MIC}_{80}(\mu \mathrm{g} / \mathrm{mL})$} \\
\hline & & $\begin{array}{l}\text { Pinobanksin-3- } \\
\text { acetate } \\
(\mathbf{2 8})\end{array}$ & $\begin{array}{l}\text { Pinocembrin } \\
(25)\end{array}$ & Chrysin (32) & Galangin (34) & $\begin{array}{c}\text { Prenyl caffeate } \\
\text { (29) }\end{array}$ & Amphotericin B \\
\hline & Candida albicans & 250 & 62 & $>250$ & $>250$ & 62 & 0.125 \\
\hline & Candida glabrata & 250 & 125 & $>250$ & $>250$ & 16 & 0.125 \\
\hline & Aspergillus fumigatus & $>250$ & 250 & $>250$ & $>250$ & 125 & 6 \\
\hline \multirow[b]{2}{*}{ Number } & \multirow[b]{2}{*}{ Bacterial strains } & \multicolumn{6}{|c|}{$\mathrm{MIC}_{100}(\mu \mathrm{g} / \mathrm{mL})$} \\
\hline & & $\begin{array}{c}\text { Pinobanksin-3- } \\
\text { acetate } \\
(\mathbf{2 8}) \\
\end{array}$ & $\begin{array}{l}\text { Pinocembrin } \\
\text { (25) }\end{array}$ & Chrysin (32) & Galangin (34) & $\begin{array}{l}\text { Prenyl caffeate } \\
\text { (29) }\end{array}$ & Oxacillin \\
\hline 22 & $\begin{array}{c}\text { Staphylococcus aureus } \\
\text { (ATCC25923) }\end{array}$ & $>100$ & $100 \pm 0$ & $>100$ & $>100$ & $63 \pm 6$ & $\leq 0.25$ \\
\hline 23 & MRSA (0706C0025) & $>100$ & $>100$ & $>100$ & $>100$ & $70 \pm 0$ & $\geq 4$ \\
\hline 24 & MRSA (0702E0196) & $>100$ & $>100$ & $>100$ & $>100$ & $70 \pm 0$ & $\geq 4$ \\
\hline 25 & MSSA (0703H0036) & $>100$ & $>100$ & $>100$ & $>100$ & $93 \pm 6$ & $\leq 0.25$ \\
\hline 26 & MSSA (0701A0095) & $>100$ & $>100$ & $>100$ & $>100$ & $93 \pm 6$ & $\leq 0.25$ \\
\hline
\end{tabular}

associated with a good antifungal activity towards Candida albicans and C. glabrata, correlated with high flavonoid contents. However only DCM based extracts (E5-6) showed a significant antibacterial activity against both methicillinresistant and methicillin-susceptible Staphylococcus aureus strains. Unfortunately these extracts are not compatible with a pharmaceutical use because of their toxicity, whereas EtOH based extracts were not as active as expected. Therefore it would be interesting to develop some alternative extraction of propolis using a nontoxic solvent such as subcritical water. In addition, it should be noticed that, as an intrinsic polytherapy, propolis may also circumvent the development of drug resistance by bacteria [60].

\section{Abbreviations}

APCI: Atmospheric pressure chemical ionization

ATCC: American Type Culture Collection

AYE: $\quad$ Patient code

CAPE: $\quad$ Caffeic acid phenylethyl ester

CBS: Centraal Bureau voor Schimmelcultures

CIP: $\quad$ Collection de l'Institut Pasteur

COSY: Correlation spectroscopy

DCM: Dichloromethane

DMSO: Dimethyl sulfoxide

EEP: $\quad$ Ethanolic extract of propolis

ESI: $\quad$ Electrospray ionization

FD: $\quad$ Flavanone/dihydroflavonol

FF: $\quad$ Flavone/flavonol

GAE: $\quad$ Gallic acid equivalent

HMBC: Heteronuclear multiple bond correlation

HMQC: Heteronuclear multiple quantum correlation

HPLC: High performance liquid chromatography

HRESIMS: High resolution electrospray ionization mass spectrometry

IR: $\quad$ Infrared
LMA: Laboratoire de Mycologie d'Angers

MIC: Minimum inhibitory concentration

MRSA: Methicillin-resistant Staphylococcus aureus

MS: $\quad$ Mass spectrometry

MSSA: Methicillin-susceptible Staphylococcus aureus

NCCLS: National Committee for Clinical Laboratory Standards

NMR: Nuclear magnetic resonance

NOESY: Nuclear Overhauser effect spectroscopy

RCH: Patient code

RP: $\quad$ Reversed phase

RPMI: Roswell Park Memorial Institute

UV: Ultraviolet

YPDA: Yeast peptone dextrose agar.

\section{Conflict of Interests}

This study was financed by Ballot-Flurin Apiculteurs Cie. There are no other competing interests.

\section{Acknowledgments}

The authors thank Mrs. Isabelle Péruchès, from BallotFlurin Apiculteurs, who provided propolis samples, Benjamin Siegler and Dr. Ingrid Freuze from the "Plateforme d'Ingenierie et Analyses Moléculaires" (PIAM) at the Faculty of Sciences in Angers for NMR and MS analyses.

\section{References}

[1] S. M. Cottica, A. C. H. F. Sawaya, M. N. Eberlin, S. L. Franco, L. M. Zeoula, and J. V. Visentainer, "Antioxidant activity and composition of propolis obtained by different methods of extraction," Journal of the Brazilian Chemical Society, vol. 22, no. 5, pp. 929-935, 2011.

[2] M. G. Miguel, S. Nunes, S. A. Dandlen, A. M. Cavaco, and M. D. Antunes, "Phenols and antioxidant activity of hydro-alcoholic 
extracts of propolis from Algarve, South of Portugal," Food and Chemical Toxicology, vol. 48, no. 12, pp. 3418-3423, 2010.

[3] I. Gülçin, E. Bursal, M. H. Şehitoĝlu, M. Bilsel, and A. C. Gören, "Polyphenol contents and antioxidant activity of lyophilized aqueous extract of propolis from Erzurum, Turkey," Food and Chemical Toxicology, vol. 48, no. 8-9, pp. 2227-2238, 2010.

[4] C. Ota, C. Unterkircher, V. Fantinato, and M. T. Shimizu, "Antifungal activity of propolis on different species of Candida," Mycoses, vol. 44, no. 9-10, pp. 375-378, 2001.

[5] A. C. H. F. Sawaya, A. M. Palma, F. M. Caetano et al., "Comparative study of in vitro methods used to analyse the activity of propolis extracts with different compositions against species of Candida," Letters in Applied Microbiology, vol. 35, no. 3, pp. 203-207, 2002.

[6] R. Raghukumar, L. Vali, D. Watson, J. Fearnley, and V. Seidel, "Antimethicillin-resistant Staphylococcus aureus (MRSA) activity of 'pacific propolis' and isolated prenylflavanones," Phytotherapy Research, vol. 24, no. 8, pp. 1181-1187, 2010.

[7] A. Kujumgiev, I. Tsvetkova, Y. Serkedjieva, V. Bankova, R. Christov, and S. Popov, "Antibacterial, antifungal and antiviral activity of propolis of different geographic origin," Journal of Ethnopharmacology, vol. 64, no. 3, pp. 235-240, 1999.

[8] M. Popova, S. Silici, O. Kaftanoglu, and V. Bankova, "Antibacterial activity of Turkish propolis and its qualitative and quantitative chemical composition," Phytomedicine, vol. 12, no. 3, pp. 221-228, 2005.

[9] S. Castaldo and F. Capasso, "Propolis, an old remedy used in modern medicine," Fitoterapia, vol. 73, supplement 1, pp. S1-S6, 2002.

[10] M. Marcucci, "Propolis: chemical composition, biological properties and therapeutic activity," Apidologie, vol. 26, no. 2, pp. 8399, 1995.

[11] V. S. Bankova, S. L. De Castro, and M. C. Marcucci, "Propolis: recent advances in chemistry and plant origin," Apidologie, vol. 31, no. 1, pp. 3-15, 2000.

[12] S. Kumazawa, T. Hamasaka, and T. Nakayama, "Antioxidant activity of propolis of various geographic origins," Food Chemistry, vol. 84, no. 3, pp. 329-339, 2004.

[13] V. Bankova, "Chemical diversity of propolis and the problem of standardization," Journal of Ethnopharmacology, vol. 100, no. 12, pp. 114-117, 2005.

[14] A. Salatino, C. C. Fernandes-Silva, A. A. Righi, and M. L. F. Salatino, "Propolis research and the chemistry of plant products," Natural Product Reports, vol. 28, no. 5, pp. 925-936, 2011.

[15] C. Velazquez, M. Navarro, A. Acosta et al., "Antibacterial and free-radical scavenging activities of Sonoran propolis," Journal of Applied Microbiology, vol. 103, no. 5, pp. 1747-1756, 2007.

[16] M. B. Agüero, M. Gonzalez, B. Lima et al., "Argentinean propolis from Zuccagnia punctata cav. (Caesalpinieae) exudates: phytochemical characterization and antifungal activity," Journal of Agricultural and Food Chemistry, vol. 58, no. 1, pp. 194-201, 2010.

[17] F. A. Santos, E. M. A. Bastos, M. Uzeda et al., "Antibacterial activity of Brazilian propolis and fractions against oral anaerobic bacteria," Journal of Ethnopharmacology, vol. 80, no. 1, pp. $1-7,2002$.

[18] H. Koo, B. P. F. A. Gomes, P. L. Rosalen, G. M. B. Ambrosano, Y. K. Park, and J. A. Cury, "In vitro antimicrobial activity of propolis and Arnica montana against oral pathogens," Archives of Oral Biology, vol. 45, no. 2, pp. 141-148, 2000.
[19] S. Mohammadzadeh, M. Shariatpanahi, M. Hamedi, R. Ahmadkhaniha, N. Samadi, and S. N. Ostad, "Chemical composition, oral toxicity and antimicrobial activity of Iranian propolis," Food Chemistry, vol. 103, no. 4, pp. 1097-1103, 2007.

[20] R. M. Darwish, R. J. A. Fares, M. H. A. Zarga, and I. K. Nazer, "Antibacterial effect of Jordanian propolis and isolated flavonoids against human pathogenic bacteria," African Journal of Biotechnology, vol. 9, no. 36, pp. 5966-5974, 2010.

[21] N. Kalogeropoulos, S. J. Konteles, E. Troullidou, I. Mourtzinos, and V. T. Karathanos, "Chemical composition, antioxidant activity and antimicrobial properties of propolis extracts from Greece and Cyprus," Food Chemistry, vol. 116, no. 2, pp. 452-461, 2009.

[22] A. G. Hegazi, F. K. Abd El Hady, and F. A. M. Abd Allah, "Chemical composition and antimicrobial activity of European propolis," Zeitschrift fur Naturforschung, Section C, vol. 55, no. 1-2, pp. 70-75, 2000.

[23] J. M. Grange and R. W. Davey, "Antibacterial properties of propolis (bee glue)," Journal of the Royal Society of Medicine, vol. 83, no. 3, pp. 159-160, 1990.

[24] S. Boisard, A.-M. Le Ray, J. Gatto et al., "Chemical composition, antioxidant and anti-AGEs activities of a French poplar type propolis," Journal of Agricultural and Food Chemistry, vol. 62, no. 6, pp. 1344-1351, 2014.

[25] V. F. de Castro Ishida, G. Negri, A. Salatino, and M. F. C. L. Bandeira, "A new type of Brazilian propolis: prenylated benzophenones in propolis from Amazon and effects against cariogenic bacteria," Food Chemistry, vol. 125, no. 3, pp. 966972, 2011.

[26] N. Sha, S.-H. Guan, Z.-Q. Lu et al., "Cytotoxic constituents of Chinese propolis," Journal of Natural Products, vol. 72, no. 4, pp. 799-801, 2009.

[27] K. Alomar, V. Gaumet, M. Allain, G. Bouet, and A. Landreau, "Synthesis, crystal structure, characterisation, and antifungal activity of 3-thiophene aldehyde semicarbazone (3STCH), 2,3thiophene dicarboxaldehyde bis(semicarbazone) $\left(2,3 \mathrm{BSTCH}_{2}\right)$ and their nickel (II) complexes," Journal of Inorganic Biochemistry, vol. 115, pp. 36-43, 2012.

[28] National Commitee for Clinical Laboratory Standards, Reference Method for Broth Dilution Antifungal Susceptibility Testing of Yeasts, National Commitee for Clinical Laboratory Standards, Villanova, Pa, USA, 1997.

[29] National Commitee for Clinical Laboratory Standards, "Reference method for broth dilution antifungal susceptibility testing of filamentous fungi, approved standard," NCCLS Document M38-A, Clinical and Laboratory Standards Institute, Villanova, Pa, USA, 2002.

[30] K. Alomar, A. Landreau, M. Kempf, M. A. Khan, M. Allain, and G. Bouet, "Synthesis, crystal structure, characterization of zinc(II), cadmium(II) complexes with 3-thiophene aldehyde thiosemicarbazone (3TTSCH). Biological activities of 3TTSCH and its complexes," Journal of Inorganic Biochemistry, vol. 104, no. 4, pp. 397-404, 2010.

[31] F. Pellati, G. Orlandini, D. Pinetti, and S. Benvenuti, "HPLCDAD and HPLC-ESI-MS/MS methods for metabolite profiling of propolis extracts," Journal of Pharmaceutical and Biomedical Analysis, vol. 55, no. 5, pp. 934-948, 2011.

[32] S. I. Falcão, N. Vale, P. Gomes et al., "Phenolic profiling of Portuguese propolis by LC-MS spectrometry: uncommon propolis rich in flavonoid glycosides," Phytochemical Analysis, vol. 24, no. 4, pp. 309-318, 2013. 
[33] F. Li, S. Awale, Y. Tezuka, H. Esumi, and S. Kadota, "Study on the constituents of mexican propolis and their cytotoxic activity against PANC-1 human pancreatic cancer cells," Journal of Natural Products, vol. 73, no. 4, pp. 623-627, 2010.

[34] P. Rubiolo, C. Casetta, C. Cagliero, H. Brevard, B. Sgorbini, and C. Bicchi, "Populus nigra L. bud absolute: a case study for a strategy of analysis of natural complex substances," Analytical and Bioanalytical Chemistry, vol. 405, no. 4, pp. 1223-1235, 2013.

[35] M. Sova, A. Perdih, M. Kotnik et al., "Flavonoids and cinnamic acid esters as inhibitors of fungal $17 \beta$-hydroxysteroid dehydrogenase: a synthesis, QSAR and modelling study," Bioorganic \& Medicinal Chemistry, vol. 14, no. 22, pp. 7404-7418, 2006.

[36] R. Correia and P. DeShong, "Palladium-catalyzed arylation of allylic benzoates using hypervalent siloxane derivatives," The Journal of Organic Chemistry, vol. 66, no. 21, pp. 7159-7165, 2001.

[37] S. Athikomkulchai, S. Awale, N. Ruangrungsi, S. Ruchirawat, and S. Kadota, "Chemical constituents of Thai propolis," Fitoterapia, vol. 88, pp. 96-100, 2013.

[38] D. Bertelli, G. Papotti, L. Bortolotti, G. L. Marcazzan, and M. Plessi, "1H-NMR simultaneous identification of health-relevant compounds in propolis extracts," Phytochemical Analysis, vol. 23, no. 3, pp. 260-266, 2012.

[39] J. Gripenberg, E. Honkanen, K. Silander, E. Stenhagen, and B. Thorell, "The structure of alpinone," Acta Chemica Scandinavica, vol. 10, pp. 393-396, 1956.

[40] Y. Park, B.-H. Moon, H. Yang, Y. Lee, E. Lee, and Y. Lim, "Complete assignments of NMR data of 13 hydroxymethoxyflavones," Magnetic Resonance in Chemistry, vol. 45, no. 12, pp. 1072-1075, 2007.

[41] K. R. Markham, K. A. Mitchell, A. L. Wilkins, J. A. Daldy, and Y. Lu, "HPLC and GC-MS identification of the major organic constituents in New Zealand propolis," Phytochemistry, vol. 42, no. 1, pp. 205-211, 1996.

[42] V. S. Bankova, "Synthesis of natural esters of substituted cinnamic acids," Journal of Natural Products, vol. 53, no. 4, pp. 821824, 1990.

[43] J.-M. Fang, W.-C. Su, and Y.-S. Cheng, "Flavonoids and stilbenes from armand pine," Phytochemistry, vol. 27, no. 5, pp. 1395-1397, 1988.

[44] W. Greenaway, T. Scaysbrook, and F. R. Whatley, "Composition of propolis in Oxfordshire, U.K. and its relation to poplar bud exudate," Zeitschrift für Naturforschung C: Journal of Biosciences, vol. 43, no. 3-4, pp. 301-304, 1988.

[45] F. Mazille, T. Schoettl, A. Lopez, and C. Pulgarin, "Physicochemical properties and photo-reactivity relationship for parasubstituted phenols in photo-assisted Fenton system," Journal of Photochemistry and Photobiology A: Chemistry, vol. 210, no. 2-3, pp. 193-199, 2010.

[46] R. Sanyal and B. V. Badami, "A new Synthesis of 3-arylpropenoic acids and 5-phenyl-2,4- pentadienoic acid from 4-acetyl-3arylsydnones and arylaldehydes," Organic Communications, vol. 2, no. 2, pp. 42-48, 2009.

[47] R. Yamauchi, K. Kato, S. Oida, J. Kanaeda, and Y. Ueno, "Benzyl caffeate, an antioxidative compound isolated from propolis," Bioscience, Biotechnology and Biochemistry, vol. 56, no. 8, pp. 1321-1322, 2014.

[48] A. H. Banskota, T. Nagaoka, L. Y. Sumioka et al., "Antiproliferative activity of the Netherlands propolis and its active principles in cancer cell lines," Journal of Ethnopharmacology, vol. 80, no. 1, pp. 67-73, 2002.
[49] H. Koshino, S.-I. Terada, T. Yoshihara et al., "Three phenolic acid derivatives from stromata of Epichloe typhina on Phleum pratense," Phytochemistry, vol. 27, no. 5, pp. 1333-1338, 1988.

[50] R. Cooper, H. E. Gottlieb, and D. Lavie, "New phenolic diglycerides from Aegilops ovata," Phytochemistry, vol. 17, no. 9, pp. 1673-1675, 1978.

[51] M. B. Agüero, L. Svetaz, M. Sánchez et al., "Argentinean Andean propolis associated with the medicinal plant Larrea nitida Cav. (Zygophyllaceae). HPLC-MS and GC-MS characterization and antifungal activity," Food and Chemical Toxicology, vol. 49, no. 9, pp. 1970-1978, 2011.

[52] J. L. Ríos and M. C. Recio, "Medicinal plants and antimicrobial activity," Journal of Ethnopharmacology, vol. 100, no. 1-2, pp. 8084, 2005.

[53] W. Krol, S. Scheller, J. Shani, G. Pietsz, and Z. Czuba, "Synergistic effect of ethanolic extract of propolis and antibiotics on the growth of Staphylococcus aureus," Arzneimittel-Forschung, vol. 43, no. 5, pp. 607-609, 1993.

[54] O. K. Mirzoeva, R. N. Grishanin, and P. C. Calder, "Antimicrobial action of propolis and some of its components: the effects on growth, membrane potential and motility of bacteria," Microbiological Research, vol. 152, no. 3, pp. 239-246, 1997.

[55] J. S. Bonvehí, F. V. Coll, and R. E. Jordà, "The composition, active components and bacteriostatic activity of propolis in dietetics," Journal of the American Oil Chemists' Society, vol. 71, no. 5, pp. 529-532, 1994.

[56] R. D. Wojtyczka, A. Dziedzic, D. Idzik et al., "Susceptibility of Staphylococcus aureus clinical isolates to propolis extract alone or in combination with antimicrobial drugs," Molecules, vol. 18, no. 8, pp. 9623-9640, 2013.

[57] S. Stepanović, N. Antić, I. Dakić, and M. Švabić-Vlahović, "In vitro antimicrobial activity of propolis and synergism between propolis and antimicrobial drugs," Microbiological Research, vol. 158, no. 4, pp. 353-357, 2003.

[58] A. Fernandes Jr., E. C. Balestrin, J. E. C. Betoni, R. D. O. Orsi, M. D. L. R. D. S. da Cunha, and A. C. Montelli, "Propolis: antiStaphylococcus aureus activity and synergism with antimicrobial drugs," Memórias do Instituto Oswaldo Cruz, vol. 100, no. 5, pp. 563-566, 2005.

[59] J. Davies and D. Davies, "Origins and evolution of antibiotic resistance," Microbiology and Molecular Biology Reviews, vol. 74, no. 3, pp. 417-433, 2010.

[60] L. C. Pamplona-Zomenhan, B. C. Pamplona, C. B. da Silva, M. C. Marcucci, and L. M. J. Mimica, "Evaluation of the in vitro antimicrobial activity of an ethanol extract of Brazilian classified propolis on strains of Staphylococcus aureus," Brazilian Journal of Microbiology, vol. 42, no. 4, pp. 1259-1264, 2011. 


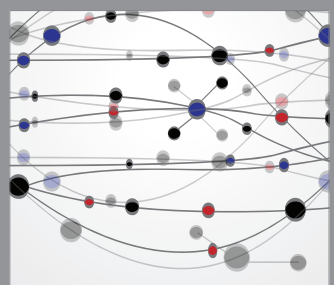

The Scientific World Journal
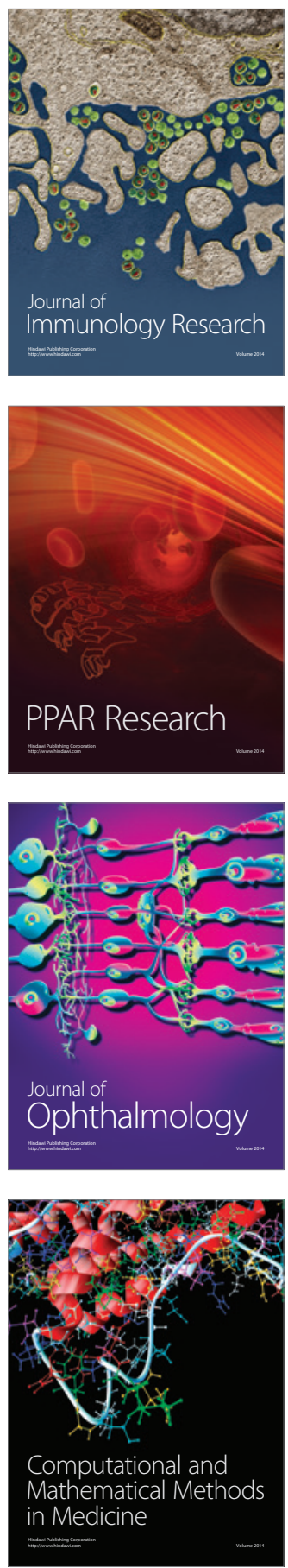

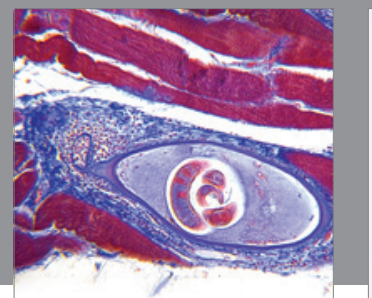

Gastroenterology

Research and Practice
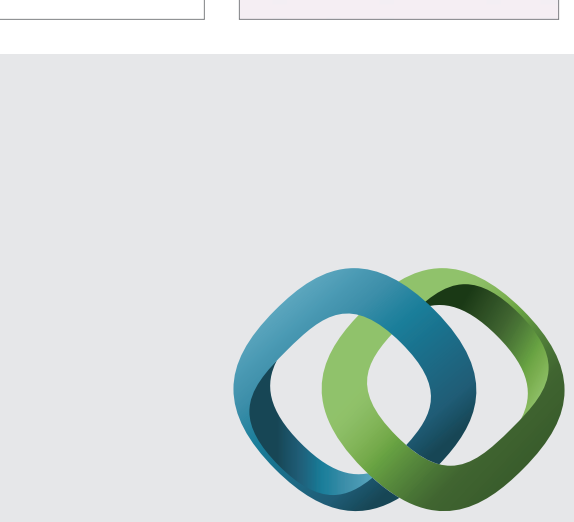

\section{Hindawi}

Submit your manuscripts at

http://www.hindawi.com
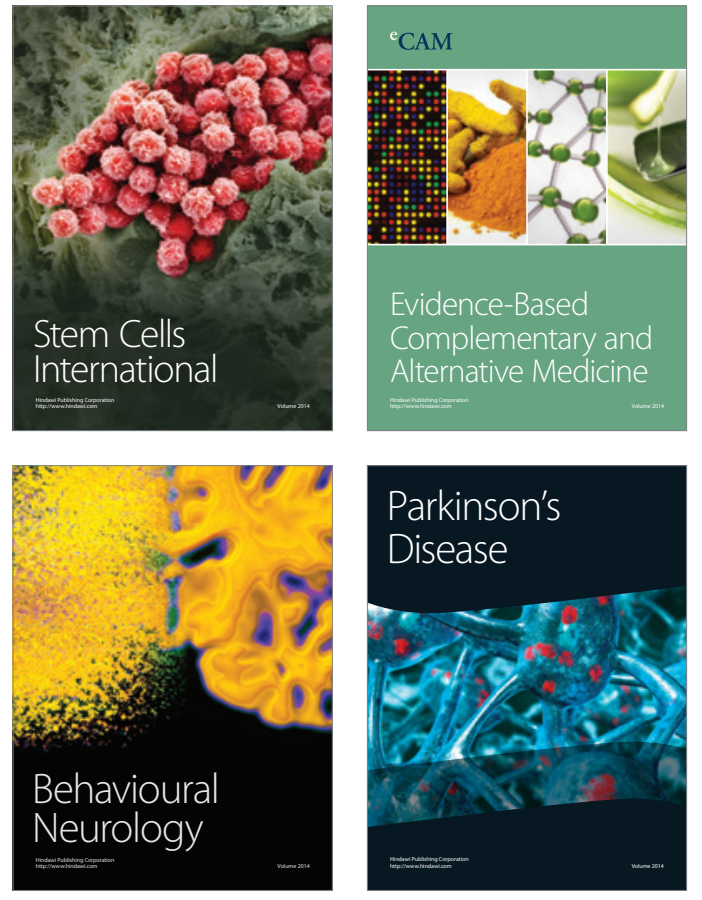
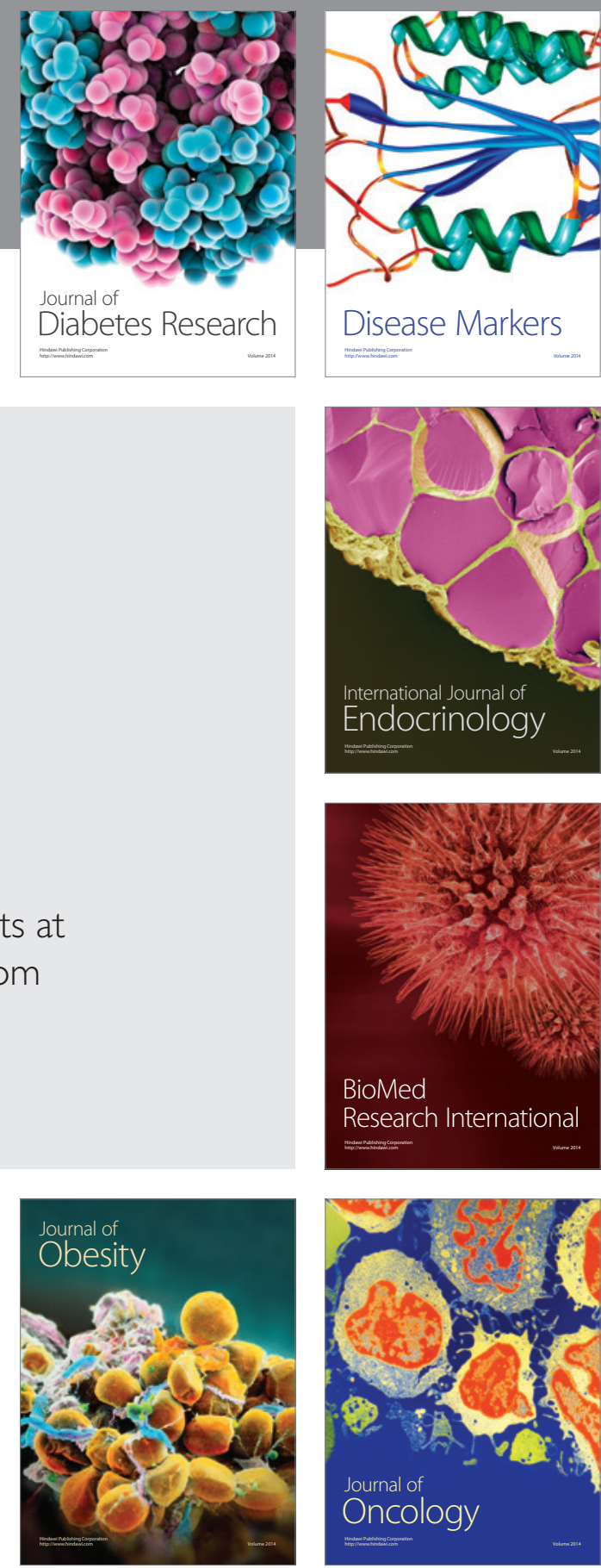

Disease Markers
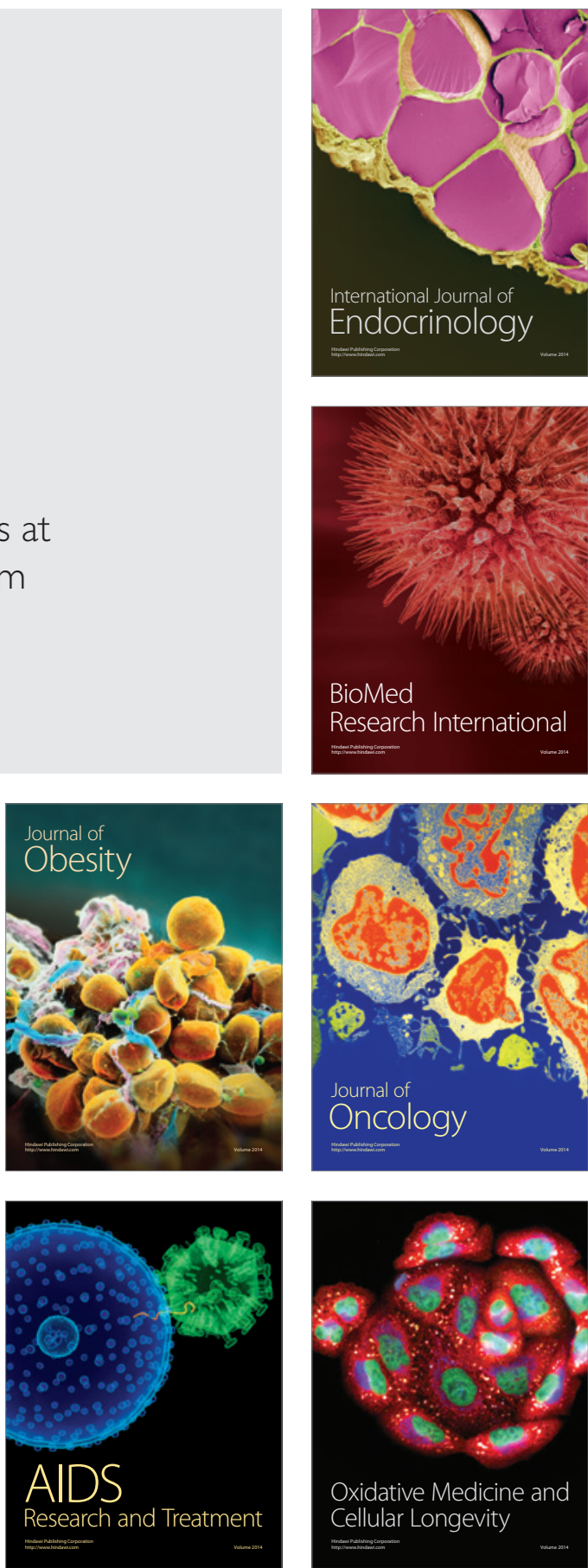